v. 7, n. 1

Vitória-ES, Jan - Apr.2010

p. 89-110 ISSN 1808-2386

DOI: http://dx.doi.org/10.15728/bbr.2010.7.1.5

\title{
Integrated ABC-EVA system as a management tool: a case study
}

\author{
Raimundo Nonato Sousa da Silva ${ }^{\dagger}$ \\ Ibmec - RJ Business School \\ Tiago de Amorim Bueno Vieira $\Omega$ \\ Ibmec - RJ Business School
}

\begin{abstract}
This paper analyses the implementation and the use of the Integrated ABC-EVA System as an engineering management tool, that identify activities which are economic value added creators and so contribute to stockholders' wealth. The motivations to rate indirect and capital costs are presented. Pre-implementation and implementation steps are illustrated using data from an implementation of the system at a mill services multinational company. The impact of the increased reliability of cost information on the company's decision-making, potential long-term business performance, and expected shareholder wealth creation is discussed.
\end{abstract}

Keywords: Activity-based costing, economic value added, costing system.

Received in 08/23/2007; accept in 03/26/2010 Corresponding authors*:

Ph.D. in Production Engineering from Rio de Janeiro

Master's in Economics from Ibmec - RJ Business School. Address: Av. Afranio de Melo Franco, 393/302, Leblon, Rio de Janeiro - RJ - Brazil - CEP 22430-060. E-mail: tabv@globo.com

Telephone: (21) 37981309 or (21) 76752093

Address: Av. Presidente Wilson no.118, Rio de Janeiro -

RJ - Brazil - CEP 24320-040.

E-mail: nonato@ibmecrj.br

Telephone: (21)45034124 Fax: (21) 45034168

Editor's note: This paper was accepted by Antonio Lopo Martinez 


\section{INTRODUCTION}

he management practices, such as: continuous improvement;

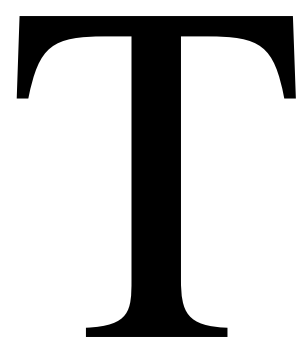

total quality; and integral management of the costs have, as a support, a system of fast and flexible information, which supplies assurance information to the administration, especially the ones related to costs of the company. Generally, the more reliable the cost information provided by the cost system is, the better will be the management of the decisionmaking and stronger will be the performance of the company (Roztocki, 2001a).

A better decision making shall be based on complete information of all the necessary costs to create a product or render a service, both the tangible and the capital cost expected by the investor and/or creditor.

The general objective of this paper is to contribute to the research and improvement of management information based on the value for activities. Also describe the two concepts that arose in the two last decades: the Activity Based Costing $(\mathrm{ABC})$ and the Economic Value Added (EVA), and how both of them, integrated and implemented in companies, may transform themselves into a management tool for decision making. Regarding the specific objectives of this paper, the intention is to demonstrate how the Integrated ABC-EVA System can be used as a management tool capable of generating information for the evaluation of the creation/destruction of each product's value.

$\mathrm{ABC}$ and EVA are management tools, which provide to the organizations a much clearer perspective of its internal and external economy. The executives that need to make decisions concerning their operations, their production processes, objectives, their products and customers should use them.

It is important to highlight the converging points between these two methodologies that certainly promote the integration. The Traditional Cost Accounting, or simply TCA, randomly allocates the indirect costs (overhead) on the cost objects, usually based on some criteria regarding volume, such as, labor hours. The ABC consists on a technique applied on the indirect costs appropriation through existing casual acknowledgement between the activities and the cost objects. Anyway, it does not take in consideration the total cost of the capital associated to that cost object. 
Whenever the managers use only the $\mathrm{ABC}$ for analyses, they have difficulties to meet the investors' expectations. The Integrated ABC-EVA System does not only comprise the cost system. Besides providing the managers with consistent information, with the correct capital cost allocation among the cost objects, it provides information on each cost object separately. After the system is implemented, the manager will be capable to evaluate the factors, components, processes or operations that are adding value to the company (Roztocki \& Needy, 1999).

Concerning the practical contribution, the research will obtain susceptible results to be used by manufacturing and service rendering companies which have raised indirect costs and investments, informing them about this tool and its applications. As this subject has not been fully studied, there are still some points to be explored and this work will help verify how it is possible to identify activities that destroy value.

The research analyses, still, a Case Study describing the development of a system in a Brazilian company that renders services in the Steel making area, with great amounts of capital employed. In a case study, though, it is not possible to infer more than the limit of the studied case.

\section{ACTIVITY BASED COSTING SYSTEM (ABC) AND ACTIVITY BASED MANAGEMENT (ABM)}

While the discussion of which is the best costing system; Costing by Traditional Absorption or Direct/Variable Costing, and if they complete each other persist throughout the years, the economy evolves and the necessity of a costing system that follows this evolution is more and more noticed.

Johnson and Kaplan (1993), state that from the 80s, the obsolescence of the cost and management control accountability systems became particularly unfavorable, on the global competition chart. The consequences of inexact products and accounting systems costs with problems in the control of processes, and the performance evaluation became a serious problem for the American industry, in an everyday more competitive market.

The ABC System was developed initially to support the manufacturing companies that needed to improve their costing management, in order to improve the production and costumers service processes, transforming the financial function from passive narrative to preventive agent for the future (Kaplan \& Cooper, 1998). 
The ABC System uses a technique in which the indirect costs are appropriated to lots of units through some bases that are not related to the factors' volumes, named drivers. The indirect costs are associated to the necessary activities to generate the products.

The ABC methodology estimates the activities consume resources and that they are necessary to the manufacture of products or services rendering. Through costs accumulation in homogenic activities, it is possible to evaluate the costs of the object costs precisely. The activities may be identified considering the company as a whole or the departments, that is, the departments may be considered activity centers. The resource distribution process to cost objects may be represented as follows:

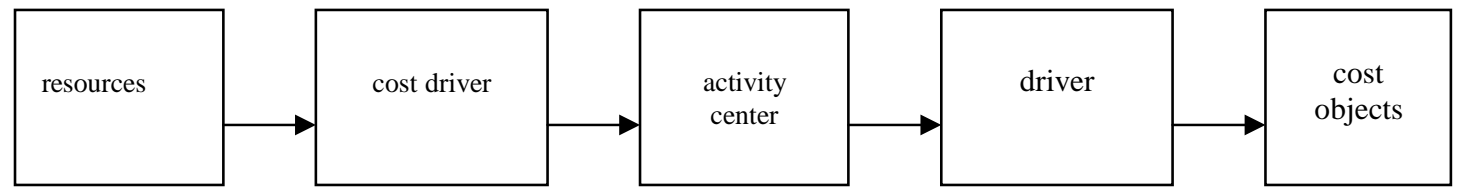

Figure 1: Cost distribution to the cost objects through ABC Source: Cogan, 1999

According to Cogan (1999), the ABC presumes that all costs from each activity center works, as they were variables, maintaining proportionality with the respective activity. The cost driver is the criteria used to demonstrate the casual relation between the resources consume by the activities and the utilization of the activities by the cost objects.

Roztoki and Needy (1998) mention that although they permit the operational costs calculation, the ABC System has failures because it does not impute the total capital cost. While the depreciation (a part of the capital cost) is considered in the ABC calculation, the interest over the capital invested in a company is not included.

Although the $\mathrm{ABC}$ costing implementation is complex, it can be very important to the company's management, because it allows the Activity Based Management ABM. This technique comprises the activity-based administration, because, in a final analysis, the activities performed inside an organization are responsible for the value generation process. So, both the ABC and EVA System are very useful in a value-based management.

The ABC is a kind of revealing instrument because when employed, it appoints the costs and its true causes, relating them to the activities and processes used in the execution of some business operations. The ABM, on the other hand, can be considered a management practice, that utilizes the economic information revealed by the $\mathrm{ABC}$, 
and that, through integrated and interdependent actions produce corrections, adjustments and improvement in the organization's status-quo. The ABM may be supported for the operational stocks, by one or more tools and continuous improvement programs like TQM (Total Quality Management), Re-Engineering, JIT (Just-in-Time) or Kaizen.

While through the traditional perspective the costs are controlled in the level of each department, in the ABM the objective goes through the employed resources optimization. According to the ABM, the costs are optimized through a correct operation management performed in the company or through elimination or minimization of the activities that do not create value. An activity adds value if it's essential for the costumer or for the functioning of the organization. That means an activity only adds value to the product when the costumer notices this value. Otherwise it becomes unnecessary.

\section{ECONOMIC VALUE ADDED (EVA)}

The concept related to the EVA is not a recent discovery. Actually, it was already applied within the residual profit concept that may be defined as the operational profit minus the capital cost. Alfred Marshal (1890), famous British economist, defined the real meaning of the economic profit as: "What remains from the profits after the deduction of the interests over the employed capital in the current rate, may be called undertaking/management real gain". The EVA is, concluding, a variable of the residual profit.

EVA's main idea is to provide the stockholders with a return that compensates the risks they are having. In other words, the return to the investments shall be, at least, the same amount of an investment with the same risk in similar market places. If this is not the case, there is not a taxable income, and, in fact, the company is operating with losses by the stockholders' point of view. On the other side, if the EVA is zero, it should be treated as a sufficient return because the stockholder received a return that compensated the risk.

Statistical analysis and academic researches show that the EVA is the measurement that most relates to the value creation, better than any other traditional measurement for accounting performance. It means that to create value, the administrators of a company must worry specially with the cost reduction and capital efficiency improvement. They must also find ways to deliver value to the costumers by BBR, Braz. Bus. Rev. (Engl. ed., Online), 
means of innovating products, successful advertisement, and impeccable services, among others (Ehrbar, 1999).

The company's decision to acquire assets or to invest in the development of new products and services, with expected return rate greater than the capital opportunity cost, usually comes together with the best financing alternatives identification, tax advantages, fiscal and others. And so, the company's administration objective is to provide the stockholders with constant appreciation of the effectuated investment, by means of a sustainable increase policy vis-à-vis value creation.

The EVA is a taxable income measure. In the arithmetic form is NOPAT - Net Operational Profit After Taxes minus the charge over the capital, appropriate for both indebtedness and stockholder's equity. The result is the value in calculated currency (dollar, pound, real, etc.) that exceeded/lacked for the capital cost used to accomplish that profit. Economists also refer to it as economic profit or residual profit that, in other words, exceeds, after all costs have been covered. The formula for the calculation is:

$\mathrm{EVA}=\mathrm{NOPAT}-\mathrm{C} \% *(\mathrm{TC})$

Where NOPAT is the net operational profit after taxes, $\mathrm{C} \%$ is the capital cost in percentage, and TC is the total capital.

Capital Cost is the minimum return rate a company could receive if it chose another investment of equivalent risk - that is, the opportunity cost of the employed resources as a result of a decision on investments (Downes \& Goodman, 1993).

Though there are several individual activities that people may pursue to create value, according to Ehrbar (1999), in the end, such activities are reduced to four categories measured by EVA increase, which are:

1) cut the costs and reduce the taxes to increase the Operational Profit ("NOPAT") without adding capital. That means, operate in a more efficient manner to gain a greater return over the capital already invested in the business;

2) undertake all the investments in which the NOPAT increase will be greater than the capital charge increase. That means to invest in profitable increase, undertaking all the present positive net value projects that compromise producing a return over the capital that exceeds the capital cost;

3) extract capital from operations when the economies originated from capital reduction, exceed any NOPAT reduction. That means, stop investing in - or 
liquidate - assets and activities that are not generating equal returns or greater than the capital cost. The greatest change in this area is the sale of assets worth more to others, but this item also includes alternatives as the storages reduction and the collection of bills to pay acceleration (both represent capital investment);

4) structure, through financial department, from the CEO and administration council, the company's finances in such a way that minimized the capital cost.

A great cost reduction, sometimes, does not automatically provide a value creation improvement, which may remain unaltered or even be reduced. Usually, the companies utilize a conflicting variety of measurements such as profit growth, profits by stocks, return over own capital, gross and net margin, tax margin, cash flow, current net value and internal return rate.

But they may not only lead to incompatible decisions concerning the value creation for stockholders, but also to conflicting decisions among themselves.An example extracted from Sr. John M. Ferguson presentation (Stern Stewart \& Co. partner) in July 2002, in São Paulo, is on Table 1 below. It consists on the analysis of a new business to a hypothetical company.

Tabela 1: Análise do novo negócio

\begin{tabular}{l|c|c|c}
\hline \multirow{2}{*}{ Revenues } & Actual Business & New Investiment & $\begin{array}{l}\text { After } \\
\text { Investiment }\end{array}$ \\
\cline { 2 - 4 } & $\$ 1.530$ & $\$ 1.540$ & $\$ 3.070$ \\
\hline Operational profit & 230 & $\$ 170$ & $\$ 400$ \\
\hline $\begin{array}{l}\text { Operational margin } \\
\%\end{array}$ & $15 \%$ & $11 \%$ & $13 \% \downarrow$ \\
\hline Capital & $\$ 1.000$ & $17 \%$ & $\$ 2.000$ \\
\hline ROI & $23 \%$ & $12 \%$ & $12 \%$ \\
\hline Capital cost & $12 \%$ & $\$ 120$ & $\$ 240$ \\
\hline Economic profit & $\$ 120$ & $\$ 50$ & $\$ 160 \uparrow$ \\
\hline EVA & $\$ 110$ & & \\
\hline
\end{tabular}

Source: John M. Ferguson presentation, 2002

The issue exposed in the example above is that if a project reduced the operational margins from $15 \%$ to $13 \%$ and the ROI (Return Over Investment) from $23 \%$ to $20 \%$, it would be adding value, considering that the company has a capital cost of $12 \%$ and the investment project has a return of $17 \%$. In this case, the answer is yes. Though, the new investment reduces the operational margins and the return over the BBR, Braz. Bus. Rev. (Engl. ed., Online), 
investment, the economic profit raise. It occurs because, though the new investment is worse if compared to its current operation, it is still sufficiently good to cover its capital costs.

The most important conclusion from this example is that, if the decision was made based on the traditional metrics of performance, it would not be investing in a project that adds value, simply because it would not be able to measure its potential correctly.

Ehrbar (1999) comments that the EVA, when fully used, is much more than a metric to sum up revenues, costs and calculate the residual profit. It is also a way to measure and manage the business performance, focusing the wealth creation to the stockholders, once it aims the stock prices increase.

\section{INTEGRATED ABC-EVA SYSTEM}

The greatest motivation of investors that are looking for new business opportunities is the expected return to its investments. The management of a profitable organization shall always aim the value creation for its stockholders, this means, generate sufficient value to cover the capital cost. If it does not occur, such organization will be destroying value, and its managing actions shall be corrected.

In order to serve the investors interests, the managers shall manage costs and economic value while they maintain a minimum profitability level. This requires constant improvement, creating value, opposing to the values manipulation to short term profits.

The traditional financing system randomly allocates the company's indirect costs on its cost objects. The ABC costing, on its turn, is based on the idea that indirect costs are generated by a number of activities necessary to the manufacture business success or business processes. As the activities consume indirect resources, and the products (projects or processes) demand activities, the product costs are related to the resource costs.

A great cost reduction, sometimes, does not automatically provide a value creation improvement, which may remain unaltered or even be reduced. This happens because the $\mathrm{ABC}$ method, though being sufficient in the operational costs calculation, it is deficient regarding the capital cost. Though the depreciation (part of the capital cost) 
is considered in the $\mathrm{ABC}$ calculation, the interests over the capital invested in the company are not (Roztocki \& Needy, 1998).

Added value performance measurements, such as the EVA, are focused on the capital cost and on the stockholders' value. Some authors recently proposed the association of the $\mathrm{ABC}$ with the EVA performance measurement system.

The EVA and $\mathrm{ABC}$ are complementary methodologies and may be used integrated, in order to provide a better performance evaluation, allowing a better capital and operational cost knowledge. Both methodologies are adequate to any kind of company (commercial, industrial or of services) and allow decisions in a long-term perspective, based on the value generation idea.

Measurement steps based on values help determining the minimum profitability level a company must have to satisfy and attract investors. The capital cost can be calculated multiplying the capital for the capital cost rate $(\mathrm{CC}=\mathrm{C} \% \mathrm{x} \mathrm{TC}$, capital charge $=$ capital cost $x$ total capital) $($ Roztocki \& Needy, 1998).

From the managing point of view, a reasonable way to consider the capital cost would be dividing it by the activities. On the other side, if randomly allocated, these activities cost would be distorted.

The $\mathrm{ABC}$ arose to try to solve the problem of arbitrary indirect cost allocation to products deficiency. According to Roztocki \& Needy (1999), the implementation method used in this work and described below was created by researchers from the University of Pittsburgh and proposed the ABC method association with the performance measurement based in value, what would include the capital cost with the $\mathrm{ABC}$ costing system.

Follow, below, the steps for the Integrated ABC-EVA System implementation, described by Roztocki \& Needy (1999), for the system implementation, that are similar to the ABC System:

- revision of the company's financial information;

- identification of the main activities and the drivers of the activities;

- resolution of each activity operational costs (using the $\mathrm{ABC}$ );

- resolution of each activity capital costs. This step is not present at ABC. As many activities consume, besides the operational costs, the capital investment, these activities' total cost is greater than the one calculated in the ABC System. As a result, 
the $\mathrm{ABC}$ tends to underestimate the cost object. The Integrated ABC-EVA System calculates the capital cost for each activity and adds it to each one of the activities, previously calculated in the ABC System;

- selection of the drivers for capital cost (capital drivers), the same way as the $\mathrm{ABC}$ implementation; and

- products cost calculation.

Though the ABC provides correct operational costs, it does not identify which products are economic value creators, which contribute to the stockholders, and which are destroyers.

In some cases, with the capital cost inclusion, the total cost of the product increases significantly. This may alter considerably the definition of what products are more profitable, or what products create value to the company. According to these results from the integrated system, other strategies may be put in practice.

The evaluation of the value creation vs. destruction by each product/service of the company, using the Integrated ABC-EVA System, may lead us to surprising conclusions. A company that works with a great amount of products and has a positive EVA, for example, may have a low result of its potential, because they have products that are creating too much value. Some products may be "disguising" the result of others.

The product-by-product evaluation, through the integrated system, brings to the company a more precise management tool regarding the value creation to investors. For this tool utilization it is essential the numbers of revenues for each activity. Otherwise, the application of this method is not possible, since there would not be a way to measure the value creation/destruction of each activity to the company.

Once implemented, the Integrated ABC-EVA System may be used as a managing tool to protect the company's decision makers that many times make shortterm choices, considering only the profitability that could destroy value in a long-term.

According to Cooper \& Slagmulder (1999), there are two main advantages in using the Integrated ABC-EVA System. Firstly, the decision maker becomes sensitive to the economic return of products and costumers, and secondly, it pays the capital usage more efficiently.

\section{CASE DESCRIPTION}


The Alfa Corporation ("Alfa") is a diversified company, with its headquarters at Camp Hill, Pennsylvania, it actuates worldwide in industrial rendering services and with high value products to great global industries.

The Company is market leader in each one of the segments it actuates which are organized in four sectors (Mill Services, Access Services, Gás \& Fluid Control, Other Infrastructure Products \& Services). More than $70 \%$ of the Alfa revenues arose from industrial services, and almost $60 \%$ are generated outside USA.

Alfa's mission is to achieve positive financial returns from its operations, creating value for its stockholders through the usage of an EVA® (Economic Value Added), evaluation model which emphasizes the optimization of the assets usage and the profits maximization. Alfa's goals are growth in the markets and technologies familiar to the Company.

The BetaServ Ltda. ("BetaServ"), whose unit chosen in Brazil is the object of this paper, is Alfa's fully subsidiary and actuates in the industrial services segment (Mill Services), mainly in the steel mill sector.

The Mill Services division actuates in Brazil since 1967, with more than 1.900 employees in 20 (twenty) sites structured within the main Brazilian steel mills' industrial units. BetaServ Brazil renders a range of services to its customers, from rawmaterial handling, such as: metallic scraps, iron ore and pig iron, to removal and processing of debris (scraps) resulting from the steel making process.

Depending on the demand and each customer's verticalization level process, BetaServ performs other activities that integrates the productive process, as an example scrap cutting and delivering for furnace feeding, torpedo-cars' operation and maintenance to transport liquid pig iron, moving and storage of products and subproducts finalize.

Most services rendered by BetaServ require great amounts of capital due to the necessity of using large tonnage equipments such as: Metal Recovery plant; crane; portal crane; loader; excavator; fork lift; pot carrier; among others.

\subsection{EVA implementation}

In February 2001, Alfa hired the Stern Stewart \& Co. to help in the EVA management system implementation. Although it already had a financial managing 
discipline, the EVA implementation allowed the company to formalize these usages under the same structure, including in the branches located outside the U.S.A, Alfa's headquarters.

Alfa decided to employ the EVA to improve the capital allocation processes, as well as to improve the system of incentive and remuneration of its employees. Alfa's efforts resulted in a model of based value management effective implementation program. The chart below shows Alfa's stocks' financial return from EVA's implementation in February 2001.

Observe that the total return for Alfa's stocks were of 22,7, comparing to $35,8 \%$ from the S\&P500. The performance is also impressing when compared to industrial companies group (Peer Group), which the average of performances in the same period reached $-10,9 \%$.



Figure 1: Return to the Stockholders since the EVA Implementation is Alfa Source: Singer \& Millar, 2003

In the EVA implementation, Alfa showed a program through Business Units levels: global BetaServ level; country BetaServ level; and, lower at each plant from each country BetaServ level.

A timetable was created and through this, at the end of 2001, the EVA management system was implemented in BetaServ Brazil. The main objects of this system were: identify created value in the investment; promote capital careful utilization; and guarantee that all the future investments add value to Alfa.

\subsection{BetaServ Brazil - MBH Unit}

The MBH Unit, belongs to one of the 20 operations from BetaServ Brazil, and will be the object of the case study from this paper. BetaServ renders 6 (six) different BBR, Braz. Bus. Rev. (Engl. ed., Online), 
types of service in the MBH unit, which are: furnace excavation and slag removal; slag wreckage and delivery; torch cutting; steel carbon metal recovery plant; scrap management; and equipment rental.Within each service, different equipments are used but all with BetaServ's operation labor, maintenance and supervision.

Besides that, the intakes for operation and maintenance (O\&M) are also BetaServ's responsibility. Next we will present a brief summary of each service rendered in the $\mathrm{MBH}$ unit. It is important to emphasize that there is no correlation among the activities.

Activity 14) Furnace Excavation and Slag Removal - slag and furnace debris cleaning process. Utilization of loaders to clean the melt shop, and dumping trucks to transport slag to the material processing area.

Activity 15) Slag wreckage and delivery - tundish scrap recovery process, ingot, skull and other material, through the drop balling process. Utilization of a crane for scrap wreckage through the drop balling process and for scrap delivery with dumping trucks.

Activity 16) Torch Cutting - tundish scrap recovery process, ingot, skull and other material, through torch cutting. To perform this activity, a hydraulic excavator is used to move the scrap and trucks to perform the delivery. Nevertheless, by the number of lancers, one can notice that it is an activity with intensive labor.

Activity 18) Metal Recovery Plants - processing of all kinds of material and others proceeding from plant processing and slag carbon scrap classification through a fixed or moving facility.

Utilization of the following equipments: metal recovery plant to separate granulometrically and magnetically the materials; loaders to supply the metal recovery plant, clean the runners, load the trucks with the processed material; and dumping trucks to deliver these materials.

Activity 22) Scrap Management - handling activity/service, preparation, separation and management of the scrap on the customers' behalf. Utilization of hydraulic excavators for scrap moving.

In order to focus attention on the methodology's demonstration, instead of accounting details, BetaServ Brazil's account plan was gathered to facilitate our study. 
The criteria used to form a group were the utilization of the same cost driver to allocate the different accounts of the group to the activities. We still tried to form account groups that did not represent less than $5 \%$ of the total manufacture cost. So, for the case study of the MBH unit, 5 (five) different groups were formed:

operation labor, considering laborers encumbrances, fiscal and welfare related to the same. This group includes all the accounts (operation salary, encumbrances, personal protection equipment, program of participation in the results, overtime, and all the benefits) referring to the cost with personal labor directly related to the operation.

supervision and Administration. Likewise the previous group, this one includes all the accounts referring to the costs with supervision of personnel labor and administration of the MBH unit, employees training, awards and insurances, signatures and associations, expenses with trips, auditing, freights, advisory, besides the material used in the office, computers and soft wares, expenses with photocopy machine, and others like (potable water, light, telephone, cleaning material, etc.).

- maintenance. This group includes the accounts referring to cost with maintenance personnel labor, besides all the material from the workshop (tools, equipment from the workshop, raw material to the workshop, etc).

- depreciation. This group represents the accounts referring to the depreciation and amortization of all equipments from the $\mathrm{MBH}$ unit, besides the account referring to equipment rent.

- consumables and maintenance. This group includes the necessary material for the equipment operation used in the MBH unit, such as diesel oil, gas, alcohol, GLP, lubricant, tires and parts.

The drivers used by the company to allocate the items related to costs of activities defined in the groups mentioned above were determined, on its great part, through interviews.

Though the services are separated by activities, there is a synergy between the equipments and labor within the operation, as we can see on the Table 2 below.

Table 2: Equipment Apportionment by Activity

\begin{tabular}{l|l|l|l|l|l}
\hline Equipment / Activity & Activity 14 & Activity 15 & Activity 16 & Activity 18 & Activity 22 \\
\hline Loader 1 & $10 \%$ & & & $90 \%$ & \\
\hline
\end{tabular}




\begin{tabular}{l|l|l|l|l|l}
\hline Loader 2 & $10 \%$ & & & $90 \%$ & \\
\hline Loader 3 & $54 \%$ & & & $46 \%$ & \\
\hline Loader 4 & $90 \%$ & & & $10 \%$ & \\
\hline Loader 5 & $100 \%$ & & & & \\
\hline Hydraulic Excavator 1 & & & & & $100 \%$ \\
\hline Hydraulic Excavator 2 & & $16 \%$ & $84 \%$ & & \\
\hline Hydraulic Excavator 3 & & & & & $100 \%$ \\
\hline MR Plant & & & & $100 \%$ & \\
\hline Crane & & $100 \%$ & & & \\
\hline Dumping Truck 1 & & & $75 \%$ & $25 \%$ & \\
\hline Dumping Truck 2 & $80 \%$ & & $75 \%$ & $25 \%$ & \\
\hline Dumping Truck 3 & & & & $20 \%$ & \\
\hline Dumping Truck 4 & & & & & \\
\hline Dumping Truck 5 & & & & & \\
\hline Source: Elaborate by the authors & & & & \\
\hline
\end{tabular}

Source: Elaborate by the authors

Likewise all other units from BetaServ Brazil, the EVA is measured based on the unit as a whole and not by activity. As described in the Item 3: EVA is the Operational Net Profit After Taxes (NOPAT) from MBH unit, minus the capital cost value in the MBH unit. Alfa's financial department determines the capital cost percentage for each country BetaServ renders service, and it is calculated based on a moderation between the debit cost and the company's net equity. This percentage is revised annually.

\section{APPLICATION OF THE INTEGRATED ABC-EVA SYSTEM IN THE SERVICE SECTOR}

The new management Integrated ABC-EVA System is being developed by BetaServ Brazil's MBH Unit and its scope comprises the costs to render services associated to this unit, as well as the activities already defined, that will be used as basis for the new system.

\subsection{Development of the Integrated ABC-EVA System in the MBH Unit}


As BetaServ Brazil owns the costs, per activity, defined for a year and understanding that detail the construction and the modeling, as well as determine the cost drivers over the $\mathrm{ABC}$, is not the goal of this paper, the three first steps for the $\mathrm{ABC}$ EVA System implantation described in Item 4, have already been implemented. Therefore, for the managing analysis through Activity Based Costing, the information would already be available and the decisions could already be made from them.

As each activity has its specific revenues, currently, BetaServ may already determine if the activity is generating operational (EBIT) profit (or loss). Though, as this cost does not contemplates the employed capital cost, one cannot determine if such activity is adding or destroying value. And it is exactly what we will search with the present case study.

The information may be viewed through the Table 3 below. The table is the summary of an Activity Managing Report from one of BetaServ's Unit, and demonstrates the total cost of each activity, through cost groups specified in the Item 5.2, that means: operation labor and benefits; supervision and administration; maintenance; depreciation; and consumables and maintenance. With the services' revenues, it was possible to obtain Gross Profit and the Gross Margin.

\section{Table 3: Managing Report Summary}

\begin{tabular}{|c|c|c|c|c|c|}
\hline $\mathrm{R} \$$ & Activity 14 & Activity 15 & Activity 16 & Activity 18 & Activity 22 \\
\hline Labor operation and refining & $\mid 12.112,22$ & $11.012,62$ & $66.615,88$ & $16.210,26$ & $15.321,70$ \\
\hline Supervision and administration & $7.001,23$ & $4.555,08$ & $24.694,65$ & $7.144,13$ & $7.789,76$ \\
\hline Maintenance & $8.468,92$ & $1.829,91$ & $1.798,84$ & $4.117,48$ & $7.254,73$ \\
\hline Depreciation & $28.411,67$ & $13.552,33$ & $9.112,50$ & $21.527,67$ & $21.500,00$ \\
\hline Consumables and maintenance & $67.085,13$ & $14.495,32$ & $14.249,18$ & $32.615,90$ & $57.467,09$ \\
\hline Total Cost & $123.079,17$ & $45.445,27$ & |116.471,05 & $81.615,42$ & 109.333,28 \\
\hline Revenue of the Services without Taxes & $150.192,00$ & $50.409,67$ & $114.278,82$ & $93.661,70$ & $133.244,83$ \\
\hline GP & $27.112,83$ & $4.964,40$ & $(2.192,23)$ & $12.046,28$ & 23.911,54 \\
\hline GM $(\%)$ & $18 \%$ & $10 \%$ & $-2 \%$ & $13 \%$ & $18 \%$ \\
\hline
\end{tabular}

Source: Elaborate by the authors 
Having this information, the next step is the capital cost calculation for each activity. In other words, the goal of this step is to allocate the total capital cost to each line of service.

For that, a capital dependency analysis table was created where, for each service line (activity), an apportionment of each accounting category was determined, subjected to a capital cost calculation, as observed on Table 4, described in the Item 5.2. A Capital Cost Rate was undertaken as $0,60 \%$ and applied over all other accounting categories.

On Units level, the accounting categories for the EVA calculation are divided in three:

- $\quad$ NBV (Net Book Value). This category represents the acquired value of the asset, minus the total already depreciated, until the respective month;

- $\quad$ inventory. In BetaServ's case, the supply is provided basically by spare parts of the equipment from the Unit; and

- $\quad$ AR (Accounts Receivable).

It is important to stand out that, in BetaServ Brazil's case, for the company's EVA calculation, besides the categories described above for the Units' level, there is still the capital cost application over the following assets: AP (Accounts Payable); the NBV of the assets are allocated in the Units, including the equipment not allocated in the Units; and all those referring to central administration and the capital adjustments.

In the MBH Unit, the apportionment of each category was performed in the following way:

- $\quad \mathrm{NBV}$ - according to the equipment used in each activity, according to Table 2, described in the Item 5.2 above. In this case, the lower the Net Book Value of the equipment used in the activity, the lower will be the cost over the capital applied in it;

- $\quad$ inventory - because it concerns spare parts, they are also apportioned according to the equipment used in each activity. As, through agreement, the services rendered by BetaServ are uninterrupted, there is a minimum quantity of parts that shall be available for a quick substitution;

- $\quad \mathrm{AR}$ - as each activity has its own revenue, the apportionment of the Accounts to be Received is done by the revenue of each one of them. 
Adding the amounts of each column, the capital cost of each service line of the company was determined.

Table 4: Capital Dependency Analysis Table

\begin{tabular}{l|c|c|c|c}
\hline$\underline{\mathrm{R} \$}$ & NBV & AR & Inventory & $\begin{array}{l}\text { Capital cost by } \\
\text { service line }\end{array}$ \\
\hline Activity 14 & 10.228 & 1.392 & 97 & 11.717 \\
\hline Activity 15 & 4.879 & 467 & 21 & 5.367 \\
\hline Activity 16 & 3.281 & 1.059 & 21 & 4.360 \\
\hline Activity 18 & 7.750 & 868 & 47 & 9.665 \\
\hline Activity 22 & 7.740 & 1.235 & 83 & 39.058 \\
\hline Total Capital Cost & 33.878 & 5.021 & 269 & 39.168 \\
\hline
\end{tabular}

Source: Elaborate by the authors

For the calculation of the taxes it was considered a rate of $34 \%$ over the operational profit. As each activity has its respective revenue, this was multiplied by the rate, finally reaching the apportionment of the taxes. The complete EVA calculation for all five activities is summarized on the Table 5 below. From the analysis of Table 5 above, one may deduce that the activity 14 is more profitable taking in consideration the Operational Profit (EBIT), followed by the activities 22, 18 and 15, that, in a decreasing order of profitability, manage to remain profitable. The activity 16 seems to show a deficit for the company, this fact was already known by the company since the ABC implantation.

Table 5. EVA Calculation

\begin{tabular}{l|l|l|l|l|l}
\hline & Activity 14 & Activity 15 & Activity 16 & Activity 18 & Activity 22 \\
\hline $\begin{array}{l}\text { Revenues of the Services without } \\
\text { Taxes }\end{array}$ & $150.192,00$ & $50.409,67$ & $114.278,82$ & $93.661,70$ & $133.244,83$ \\
\hline Operational Profit (EBIT) & $27.112,83$ & $4.964,40$ & $(2.192,23)$ & $12.046,28$ & $23.911,54$ \\
\hline Taxes & $9.218,36$ & $1.687,90$ & $(745,36)$ & $4.095,73$ & $8.129,92$ \\
\hline $\begin{array}{l}\text { Net Operational Profit After Taxes } \\
\text { NOPAT) }\end{array}$ & $17.894,47$ & $3.276,50$ & $(1.446,87)$ & $7.950,54$ & $15.781,62$ \\
\hline Capital Cost (NBV) & $10.228,20$ & $4.878,84$ & $3.280,50$ & $7.749,96$ & $7.740,00$ \\
\hline Capital Cost (AR) & $1.391,95$ & 467,19 & $1.059,12$ & 868,04 & $1.234,89$ \\
\hline
\end{tabular}




\begin{tabular}{l|l|l|l|l|l}
\hline Capital Cost (Inventory) & 97,01 & 20,96 & 20,60 & 47,16 & 83,10 \\
EVA & $6.177,31$ & $(2.090,48)$ & $(5.807,09)$ & $(714,62)$ & $6.723,63$ \\
\hline
\end{tabular}

Source: Elaborate by the authors

Nevertheless, the analysis of the results obtained by the new Integrated ABCEVA System provided value information to BetaServ's managers. The activities 14 and 22 , for example, demonstrate create economic value for the company, considering that the revenue generated by the rendering of service was capable of restoring all the service associated costs. On the other hand, the Activities 15 and 18, which generated operational profit to the company, were in fact, destroying the stockholder's value, as the total costs of these services were greater than the generated revenues.

The comparison between the costs informed by both systems shows that if we consider only the operational profit (EBIT), obtained through the ABC System, we would not have detected three activities destroying the company's value.

In order to determine precisely the reasons why three activities are destroying stockholder's value, we need to make a detailed analysis of its operational costs, of the dimension used in each one of them, besides the practiced prices. In the specific case of the Activity 16, in the costing per activity it had already been detected that it concerned a service, which generated loss to the company. Its operational cost was greater than the revenue. This, together with the capital cost, transforms this activity in the one that most destroys value in the MBH Unit. However, in the case of the Activities 15 and 18, if we only analyze the Table 4 of Capital Deficiency Analysis, we notice that the greatest capital cost weight concentrates in the item NBV, the one related to the net book value of the equipment used. Therefore, though such activities generate operational profit, this profit is not capable of surpassing the total capital responsibility.

Another important observation is the analysis of Activity 14's operational profit, which is the most profitable out of the five activities. Although, it is an activity that uses more capital than the others, it consequently has a greater capital cost. It makes the Activity 22, which had an EBIT smaller; add more value to the company than the Activity 14. 
The total EVA from Unit MBH and from each activity may be perceived on the Table 6. As observed, when the analysis is made under the EVA perspective, one can notice that the MBH Unit is adding value to the stockholder.

Though, only by the Integrated ABC-EVA System we can detect activities that were destroying value. Therefore, it characterizes the existence of a crossed subsidy, whereas in the former system the Activities 14 and 22 subside the other services in generating value.

Table 6: Total EVA and per Activity

\begin{tabular}{ll|l|l|l|l|l}
\hline & TOTAL & Activity 14 & Activity 15 & Activity 16 & Activity 18 & Activity 22 \\
EVA & $4.288,74$ & $6.177,31$ & $-2.090,48$ & $-5.807,09$ & $-714,62$ & $6.723,63$ \\
\hline
\end{tabular}

Source: Elaborate by the authors

Obtaining this information, there are some decision options the managers from BetaServ can make. Among the possible decisions, they could optimize the equipments from the MBH Unit, especially of the activities that would be destroying value. That means, verify and analyze these activities' equipment fleet, in order to re-dimension them.

To do so, the underused equipment could be sold; the usage of the equipment from the unit could be optimized, consequently increasing the utilization of those, which remained in operation. Thus, the assets of the unit would be reduced, mainly the ones from these activities.

Another possibility is the replacement of the equipments by others with lower NBV. All these solutions are directly connected to the capital cost referring to the NBV. This category is responsible by $86 \%$ of the Unit's total capital cost and therefore is the one, which would reflect more strongly on the stockholders' value.

The reduction of the AR consists on another option for the managers. So, there are two possibilities: try, through negotiation with the customer, reduce the payment term; and find all the invoices that were not paid in order to obtain a final solution.

One could still try to reduce the operational costs; increase the revenues by raising the prices; increase the amount of services rendered within the same activity, in order to increase the revenue without increasing the capital investment (it means to use the same equipment to obtain more revenues); and/or even try to replace the equipment in the marketplace to obtain better productiveness and lower costs to increase the created value. 
The responsibilities described above are only a few possible managing decision strategies for the Activities 15, 16 and 18 from BetaServ's MBH Unit. In parallel, the company should make a decision concerning the Activities 14 and 22, which by the Integrated ABC-EVA System information, demonstrate to be more attractive. One could, for example, increase the marketing efforts in order to announce these services.

Thus, the new cost system acceptance allows BetaServ's high managing division to make managing decisions, based on the most accurate cost and services calculation.

\section{CONCLUSION}

The paper demonstrated how the Integrated ABC-EVA System could be used as a management tool capable of generating information for the evaluation of the value creation/destruction of each product.

The information extracted from the analysis of the results obtained by the case study in this paper, applying the Integrated ABC-EVA System, revealed the magnitude of the differences confirmed between the analysis of the ABC System and the approach of the integrated ABC-EVA.

Though, the ABC provides precise information on the products' operational costs, it does not identify which are economic value creators and, consequently, contribute for its stockholders' health.

Regarding the main conclusions of this paper, one is that it is possible to obtain a technically more consistent answer about the total cost of the services, when the value creation approach concept to the stockholder for each activity is used by means of the Integrated ABC-EVA System.

\section{REFERENCES}

COGAN, Samuel. Custos e preços: formação e análise. (Costs and prices: constitution and analysis). São Paulo: Editora Pioneira, 1999.

COOPER, Robin; KAPLAN, R. S. Atividade based systems: measuring the costs of resource. 1992.

.; SLAGMULDER, Regine. Integrating atividade-based costing and economic value added. Management Accounting, Jan. 1999.

DOWNES, John; GOODMAN, Jordan E. Dicionário de termos financeiros e de investimento. (Dictionary of Investment and Financial Terms). São Paulo: Nobel, 1993. 
EHRBAR, Al. EVA: Valor Econômico Agregado: a verdadeira chave para a criação de riqueza. (EVA: Economic Value Added: the true key to create wealth). Tradução de Bazán Tecnologia e Lingüística (translated by Bazán Technology and Linguistics). Rio de Janeiro: Qualitymark, 1999.

GARRISON, Ray H; NOREENN, Eric W. Contabilidade gerencial. (Managing Accounting). 9. ed. Rio de Janeiro: LTC Editora, 2001.

JOHNSON, Thomas H.; KAPLAN, Robert S. Contabilidade gerencial: a restauração da relevância da contabilidade nas empresas. (Managing Accounting: the restoration of the accounting relevance in the companies). Rio de Janeiro: Campus, 1993.

KAPLAN, Robert S. Contabilidade gerencial. (Managing accounting). 2. ed. São Paulo: Atlas, 2000.

.; COOPER, R. Custo e desempenho: administre seus custos para ser mais competitivo. (Cost and Performance: manage your costs to become more competitive). São Paulo: Editora Futura, 1998.

ROZTOCKI, N.; NEEDY, K. L. (1998). An Integrated activity-based costing and economic value added system as an engineering management tool for manufacturers. In: AMERICAN SOCIETY FOR ENGINEERING MANAGEMENT (ASEM National Conference), 1998. Anais...1998, p. 77- 84.

(1999). How to design and implement an integrated activity-based costing and economic value added system. In: INDUSTRIAL ENGINEERING RESEARCH, 1999 Conferences. Anais...1999.

(2000). The Integrated activity-based costing and economic value added system as strategic management tool: a field study. In: CONFERENCE ON MANUFACTURING AND MANAGEMENT, 2000. Anais...2000, p. 84-89.

(2001a). The Integrated activity-based costing and economic value added system for the service sector. In: INTERNATIONAL CONFERENCE ON SERVICE MANAGEMENT, 2001. Anais...2001, p. 387-397.

(2001b). Using the integrated atividade-based costing and economic value added system for project management. In: SEVENTH AMERICAS CONFERENCE ON INFORMATION SYSTEMS, 2001. Anais...2001, p. 1454-1460.

SILVA, Adolfo H.; PESSANHA Diogo S.; FERREIRA, Paulo R.; COGAN, Samuel (2002). Uma Contribuição à utilização do EVA como um modelo de gestão: integrando o EVA e o ABC. (A Contribution to the usage of EVA as a management model: integrating the EVA and the ABC). In: ENCONTRO DA ASSOCIAÇÃO NACIONAL DE PROGRAMA DE PÓS-GRADUAÇÃO EM ADMINISTRAÇÃO (ENANPAD), 26., 2002, Salvador (BA). Anais...Salvador: ENANPAD, 2002.

VERGARA Sylvia C. Projetos e relatórios de pesquisa em administração. (Projects and research reports on administration.).São Paulo: Atlas, 1997. 